\title{
PERILAKU MASYARAKAT DALAM MENJAGA KEBERSIHAN LINGKUNGAN LINGKUNGAN PANTAI KECAMATAN SASAK RANAH PASISIE KABUPATEN PASAMAN BARAT
}

\author{
Devi Hardiana \\ Program Studi Pendidikan Geografi, \\ Fakultas Ilmu Sosial, Universitas Negeri Padang \\ Email: devihardiana@gmail.com
}

\begin{abstract}
Abstrak
Penelitian ini dilatar belakangi oleh perilaku masyarakat dalam menjaga kebersihan lingkungan Pantai Sasak Kecamatan Sasak Ranah Pasisie yang cenderungan membuang sampah ke pinggir pantai. Penelitian ini bertujuan untuk mengetahui perilaku masyarakat dalam menjaga kebersihan lingkungan Pantai Sasak Kecamatan Sasak Ranah Pasisie Kabupaten Pasaman Barat. Untuk mengetahui perilaku masyarakat dalam menjaga kebersihan lingkungan pantai sasak menggunakan pendekatan kualitatif, jumlah informan yang digunakan sebanyak 30 orang. Berdasarkan hasil penelitian diperoleh: 1) Perilaku masyarakat tentang kebersihan lingkungan Pantai Sasak masih kurang baik, disebabkan masyarakat membuang sampah, mengumpulkan kemudia membakarnya di pinggir pantai, tidak hanya itu masyarakat juga buang air besar dan membuang limbah air garam ke pinggir pantai yang menyebabkan kondisi lingkungan pantai menjadi kurang bersih. 2) Upaya masyarakat dalam menjaga kebersihan lingkungan Pantai Sasak dengan membersihkan pekarangan rumah pribadi yang berada di area lingkungan Pantai Sasak sedang kan untuk masalah sampah sendiri upaya yang dilakukan hanya membakar nya saja. 3) Peran pemerintah daerah dalam menjaga kebersihan lingkungan pantai dengan cara melakukan sosialisasi tentang pentingnya menjaga kebersihan lingkungan pantai kepada masyarakat dan menyediakan tempat sampah, terkait dengan MCK Pemerintah Daerah telah membuatkan sumur beserta WC. Hasil penelitian menunjukkan bahwa perilaku masyarakat dalam menjaga kebersihan lingkungan pantai masih tergolong rendah.
\end{abstract}

Kata kunci : Kepedulian Masyarakat, Sampah, dan Kebersihan Lingkungan.

\begin{abstract}
The study is based on the lack of public behavior in maintaining the cleanliness of the Sasak Beach environment, Sasak Ranah Pasisie Subdistrict, which tend to throw garbage to the edge of the beach. The aim of the study is to determine public behavior in maintaining the cleanliness of the environment Sasak Beach Sasak Ranah Pasisie District Pasaman Barat. In order to know the public behavior in maintaining cleanliness of Sasak beach environment, qualitative approach is used in this study, then the number of informants used are 30 people. The finding of this research are : 1) the public behavior related to the cleanliness of the Sasak Beach environment is still not attentive due to they throw garbage, then collect it and burn it on the beach, not only that the public also defecate and dispose of salt water waste to the edge of the beach so it causes the beach environment conditions to be cleanless. 2) Public efforts in maintaining the cleanliness of the Sasak Beach environment by cleaning the yard of a private house which located in the area of Sasak Beach is on the way to the problem of own garbage efforts that are done just burn it alone. 3) The role of local government in maintaining the cleanliness of the beach environment by giving socialization about the importance of maintaining the cleanliness of the beach environment to the public and providing waste bins, associated with the MCK Local Government has made wells along with WC. The results showed that public behavior in maintaining beach environment cleanliness is still at the low level.
\end{abstract}

Keywords: Public Care, Garbage, and Environmental Hygiene

${ }^{1}$ Mahasiswa Program Strudi Pendidikan Geografi untuk Wisuda Maret 2018

${ }^{2}$ Dosen ajaurusan Geografi Fakultas Ilmu Sosial Universitas Negeri Padang: Pembimbing I Dr. Iswandi Umar, S.Pd, M.Si, Pembimbing II Rery Novio, S.Pd, M.Pd. 


\section{PENDAHULUAN}

Lingkungan hidup merupakan rahmat Tuhan Yang Maha Esa, wajib dikembangkan kemampuanya agar tetap menjadi sumber dan penunjang semua makluk hidup, khususnya manusia dalam mengelola lingkungan hidup agar terarah sesuai dengan tujuan yang diinginkan, maka pemerintah pusat dan daerah telah berupaya membuat kebijakan-kebijakan mengamankan terciptanya kehidupan yang sejahtera lahir dan batin dalam suatu lingkungan hidup yang baik dan sehat. Kebersihan lingkungan mempunyai arti sebuah keadaan bebas dari kotoran, termasuk diantaranya, debu, sampah, dan bau. Kebersihan merupakan upaya menusia untuk memelihara diri dan lingkungannya dari segala yang kotor dan keji dalam rangka mewujudkan dan melestarikan kehidupan yang sehat dan nyaman (Nazaruddin, 2014). Selanjutnya Sampah adalah sebagian dari sesuatu yang tidak dipakai, tidak disenangi, atau sesuatu yang harus dibuang, yang umumnya berasal dari kegiatan yang dilakukan oleh manusia. Kegiatan manusia yang mencemari lingkungan dengan membuang sampah sembarangan dapat mengurangi kebersihan lingkungan (Azwar (1979).

\section{Berdasarkan Permen Pekerjaan}

Umum Nomor 21 tahun 2006 tentang kebijakan dan strategi nasional pengembangan sistem pengelolaan sampah memiliki visi yaitu pemukiman sehat yang bersih dari sampah. Untuk mencapai visi tersebut dimasa depan, maka misi-misi yang harus dilakukan adalah mengurangi timbunan sampah dalam rangka pengelolaan persampahan yang berkelanjutan, meningkatkan jangkauan dan kualitas pelayanan sistem pengelolaan persampahan, memberdayakan masyarakat dan meningkatkan peran aktif dunia usaha swasta, meningkatkan kemampuan manajemen dan kelembagaan dalam sistem pengelolaan persampahan, mobilisasi dana dari berbagai sumber untuk pengembangan pengelolaan sampah dan menegakkan hukum dan melengkapi peraturan perundangan untuk meingkatkan sistem pengelolaan persampahan.

Iswandi (2012) sampah dapat sumber dari beberapa kategori antara lain: sampah rumah tangga dan sampah perdagangan. Sampah rumah tangga merupakan sampah yang dihasilkan pada umumnya berupa sisa makanan, bahan dan peralatan yang sudah tidak terpakai, bahan pembungkus, kertas, plastik dan sebagainya, sedangkan tempat perdagangan dan sampah perdagangan merupakan sampah yang dihasilkan misalnya, bahan dagangan yang rusak, buah, sayur, kertas, karton dan sebagainya.

Kecamatan Sasak Ranah Pasisie merupakan salah satu kecamatan dari tujuh kecamatan yang ada di Kabupaten Pasaman Barat dan merupakan kecamatan terkecil yang ada di Pasaman Barat dengan luas wilayah $123,71 \mathrm{Km}$ dan jumlah penduduk 13.860 jiwa dengan 
kepadatan penduduk $1,12 \mathrm{jiwa} / \mathrm{km}^{2}$ yang tersebar di 7 jorong (Sumber Kantor Wali Nagari, 2016). Kecamatan Sasak Ranah Pasisie merupakan daerah yang memiliki pantai.

Keadaan Pantai Sasak berdasarkan observasi yang dilakukan memprihatinkan hal ini dilihat dari sampah yang berserakan di lingkungan pantai, sampah yang berada di pinggir pantai berasal dari sampah rumah tangga masyarakat yang bermukim di sepanjang pinggir pantai dan juga sampah yang berasal dari laut. Kebersihan pantai tidak terjaga dengan baik dengan ditemukannya sampah yang bertumpukan di pinggir pantai, serta adanya pembuangan limbah berupa air garam hasil dari pengasinan ikan asin yang dibuang di pinggir pantai oleh masyarakat yang berprofesi sebagai pembuat ikan asin yang menimbulkan bau busuk di pinggir pantai. Tidak hanya sampah dan limbah air garam, kotoran sapi dan kotoran manusia juga ikut menjadi penyebab kotor nya lingkungan pantai. Hal demikian terjadi di dua jorong di Kecamatan Sasak Ranah Pasisie yaitu Jorong Pondok dan Jorong Pasa Lamo. Jenis sampah yang terdapat di lingkungan Pantai Sasak, berupa sampah plastik, kaleng bekas minuman, kertas, bangkai hewan, kotoran sapi, kayu dan lain sebagainya.

Berdasarkan permasalahan di lapangan yang ditemukan peneliti. Kepedulian masyarakat yang kurang terhadap lingkungan yang bersih terutama dalam pengelolaan sampah dan kebersihan Pantai Sasak. Peneliti tertarik mengetahui bagaimana kepedulian masyarakat terhadap kebersihan lingkungan pantai. Sehingga peneliti mengangkat penelitian mengenai "Kepedulian Masyarakat Dalam Menjaga Kebersihan Lingkungan Pantai Kecamatan Sasak Ranah Pasisie Kabupaten Pasaman Barat".

Perilaku timbul dari sebuah persepsi dan sikap terhadap kecenderungan seseorang untuk bertindak pada sesuatu dengan cara tertentu, dalam kamus besar Bahasa Indonesia perilaku adalah tanggapan atau reaksi individu terhadap rangsangan atau lingkungan. Tanggapan atau reaksi tersebut dinyatakan dalam bentuk kegiatan, perbuatan atau tindakan yang bertujuan sesuai dengan sifat rangsangan itu sendiri. Adanya perilaku sebagai suatu respon merupakan akibat dari adanya rangsangan sebagai penyebab.

Perilaku adalah sebagai suatu fungsi dari interaksi antara person atau individu dengan lingkungannya. Setiap manusia memiliki perilaku berbeda satu dengan yang lain dan perilaku ini ditentukan oleh pengaruh lingkungan yang berbeda. Sifat-sifat manusia dapat dilihat dari perilakunya, untuk itu ada beberapa prinsip dasar manusia yang berhubungan dengan perilaku, seperti dikemukakan oleh (Thoha, 2008).

1) Manusia berbeda perilakunya karena kemampuannya tidak sama.

Prinsip dasar kemampuan amat penting diketahui karena dengan terbatasnya kemampuan, maka seseorang akan bertingkah laku yang 
berbeda. Hal ini dilakukan karena keinginan manusia, dimana untuk mewujudkan keinginan tersebut muncullah berbagai perilaku. Perbedaan kemampuan ada yang dianggap disebabkan sejak lahir ada ada pula yang dianggap disebabkan oleh takdir. Kecerdasan merupakan salah satu aspek yang berpengaruh terhadap tingkah laku seseorang.

2) Manusia mempunyai kebutuhan yang berbeda.

Perilaku muncul didorong oleh serangkaian kebutuhan. Dengan kebutuhan ini menyebabkan seseorang berbuat untuk mencapainya sebagai seuatu objek atau hasil. Kebutuhan seseorang berbeda dengan kebutuhan orang lain. Kadangkala seseorang yang telah berhasil memenuhi kebutuhan yang satu, kebutuhannya akan berubah atau berkembang. Pemahaman kebutuhan yang berbeda dari seseorang ini akan bermanfaat untuk memahami konsep perilaku seseorang.

3) Cara berpikir.

Kebutuhan-kebutuhan manusia dapat dipenuhi lewat perilakunya masingmasing. Dalam banyak hal, seseorang dihadapkan dengan sejumlah kebutuhan potensial yang harus dipenuhi lewat perilaku yang dipilihnya. Kekuatan akan mendorong seseorang untuk berperilaku dalam suatu cara tertentu akan menjadi besar, apabila individu tersebut: (1) percaya pelaksanaan kerja pada suatu tingkat yang ia inginkan tersebut memungkinkan, (2) percaya bahwa perilakunya akan mendapatkan hasil dan (3) hasil yang dicapai yang mempunyai nilai.

Menurut Azwar (2005), beberapa metode pengukuran perilaku seseorang:

a) Observasi perilaku, untuk mengetahui perilaku seseorang terhadap sesuatu dapat diperhatikan melalui perilakunya.

b) Pertanyaan langsung, ada dua asumsi yang mendasari penggunaan metode pertanyaan langsung guna mengungkapkan perilaku. Pertama, asumsi bahwa individu merupakan orang yang paling tahu mengenai dirinya sendiri. Kedua, asumsi keterus terangan bahwa manusia akan mengemukakan secara terbuka apa yang dirasakannya. Oleh karena itu dalam metode ini, jawaban yang diberikan oleh mereka yang ditanyai dijadikan indikator perilaku mereka. Akan tetapi, Metode ini akan menghasilkan ukuran yang valid hanya apabila situasi dan kondisinya memungkinkan kebebasan berpedanpat tanpa tekanan Psikologis maupun fisik.

c) Pengungkapkan Langsung, pengunkapkan langsung secara tertulis dapat dilakukan dengan menggunakan item tunggal maupun dengan menggunakan item ganda.

d) Sakala Sikap, berupa kumpulan pernyataan-pernyataan mengenai 
suatu objek perilaku. Salah satu skala perilaku adalah isi pernyataannya yang dapat berupa pernyataan langsung yang jelas tujuan pengukurannya akan tetapi dapat pula berupa pernyataan tidak langsung yang tampak kurang jelas tujuan pengukurannya bagi responden.

e) Pengukuran terselubung, objek pengamatan bukan lagi perilaku yang tampak didasari atau sengaja dilakukan oleh seseorang melainkan reaksi- reaksi fisiologis yang terjadi di luar kendali orang yang bersangkutan.

Perilaku masyarakat di Kecamatan Sasak Ranah Pasisie mengenai kebersihan lingkungan pasih tergolong tidak baik. Terlihat dari lingkungan pantai khsusnya di jorong pondok dan jorong pasa lamo yang disana banyak terdapat kotoran sapi, limbah air garam dan sampah.

Permen Nomor 33 Tahun 2010 Tentang Pedoman Pengelolaan Sampah, mendefenisikan sampah adalah sisa kegiatan sehari-hari manusia dan proses alam yang berbentuk padat yang terdiri dari sampah rumah tangga maupun sampah sejenis sampah rumah tangga. Sampah rumah tangga yaitu sampah yang berasal dari kegiatan sehari-hari dalam rumah tangga yang sebagian besar terdiri dari sampah organik, tidak termasuk tinja dan sampah spesifik.

Sampah pada dasarnya merupakan suatu bahan yang terbuang atau dibuang dari sumber hasil aktivitas manusia maupun proses-proses alam yang tidak mempunyai nilai ekonomi, bahkan dapat mempunyai nilai ekonomi yang negatif karena dalam penggunaannya baik untuk membuang atau membersihkannya perlu biaya yang cukup besar. Menurut Azwar (1979) Sampah adalah sebagian dari sesuatu yang tidak dipakai, tidak disenangi, atau sesuatu yang harus dibuang, yang umumnya berasal dari kegiatan yang dilakukan oleh manusia.

Sampah merupakan salah satu masalah penyebab penyakit tidak seimbangnya lingkungan hidup, yang umumnya terdiri dari komposisi sisa makanan, daun-daun, plastik, kain bekas, karet, tanah dan lain-lain. Sedangkan Nugroho (2007) berpendapat bahwa sampah adalah bahan sisa atau produk sampingan dari kegiatan manusia yang sudah tidak berguna dan kemudian dibuang (waste), sehingga bias menyebabkan gangguan estetika, kerusakan dan pencemaran lingkungan, atau mengandung unsur berbahaya, serta dapat mengganggu kelestarian dan kesehatan kehidupan manusia dan lingkungan.

Sedangkan Neolaka (2008)
menjelaskan Sampah adalah segala
sesuatu yang tidak diperlukan lagi oleh
pemiliknya. Sampah adalah salah satu
masalah penyebab lingkungan kotor,
umumnya sampah terdiri dari
komposisi sisa makanan, daun-daun,
plastik, kain keras, karet, tanah dan lain-
lain. Pencemaran lingkungan akibat
sampah, seperti perilaku manusia yang
membuang sampah sembarangan dan


menumpukkan sampah akan menimbulkan bau dan gas-gas berbahaya sehingga berbahaya bagi kesehatan manusia.

$$
\text { Jenis-jenis sampah menurut }
$$
Iswandi (2012) terdiri dari:

1) Sampah Organik

Sampah organik berasal dari bahanbahan penyusun tumbuhan dan hewan yang diambil dari alam atau dihasilkan dari kegiatan pertanian, perikanan atau yang lain. Sampah rumah tangga sebagian besar merupakan bahan organik, misalnya sampah dari dapur, sisa tepung, sayuran, kulit dan daun.

2) Sampah Anorganik

Sampah anorganik berasal dari sember daya alam tak terbaharui seperti mineral dan minyak bumi, atau dari proses industri. Seperti plastik, botol dan kaleng.

3) Sampah Khusus

Sampah khusus adalah sampah yang memerlukan penanganan khusus untuk menghindari bahaya yang akan ditimbulkannya. Seperti bola lampu, pelarut dan cat, zat-zat kimia pembasmi hama dan penyakit tanaman seperti pestisida.

Sumber sampah menurut Iswandi (2012) terdiri dari:

1) Rumah Tangga

Sampah yang dihasilkan umumnya berupa sisa makanan, bahan dan peralatan yang sudah tidak terpakai, bahan pembungkus, kertas, plastik, dan sebagainya.

2) Tempat Perdagangan

Sampah yang dihasilkan seperti bahan dagangan yang rusak, buah, sayur, kertas, plastic, karton dan sebagainya.

3) Perkebunan

Sampah yang dihasilkan dari kegiatan pertanian tergolong pada sampah organik, seperti jerami dan sejenisnya.

4) Sisa Bangunan dan Kontruksi Gedung Sampah yang berasal dari kegiatan pembangunan dan pemugaran gedung bias berupa bahan organik maupun anorganik, seperti kayu, bamboo, triplek. Sampah anorganik, seperti semen, pasir, spesi batu bata, ubin, besi dan baja, kaca dan kaleng.

Sampah adalah bahan yang tidak mempunyai nilai atau tidak berharga untuk maksud biasa atau utama dalam pembikinan atau pemakaian barang rusak atau cacat dalam pembuatan manufaktur atau materi berlebihan atau ditolak atau buangan. Dalam undang-undang No. 18 tentang Pengelolaan Sampah dinyatakan definisi sampah sebagai sisa kegiatan sehari-hari manusia dan/atau dari proses alam yang berbentuk padat. Nugroho (2007) dalam Marita (2015) berpendapat bahwa sampah adalah bahan sisa atau produk sampingan dari kegiatan manusia yang sudah tidak berguna dan kemudian dibuang (waste), sehingga bisa menyebabkan gangguan estetika, kerusakan dan pencemaran lingkungan, atau mengandung unsur berbahaya, serta dapat mengganggu kelestarian dan 
kesehatan kehidupan manusia dan lingkungan.

Lingkungan adalah faktor-faktor yang membentuk lingkungan sekitar organisme, terutama komponenkomponen yang mempengaruhi perilaku, reproduksi, dan kelestarian organisme. Kebersihan merupakan suatu keadaan yang tampak bersih, sehat dan indah. Lingkungan yang bersih merupakan hak dasar setiap manusia dalam memperoleh kesehatan dalam penghidupannya. Segala sesuatu yang terjadi di lingkungan akan berpengaruh terhadap kelangsungan kehidupan dan kesejahteraan manusia dan makhluk hidup lainnya. dalam menjaga lingkungan yang bersih perlu kesadaran diri manusia sebagai makhluk yang memiliki pikiran (Arifin, 2012).

Lingkungan menurut Kamus Umum Bahasa Indonesia, Poerwadarminta (1976), adalah berasal dari kata lingkungan yaitu sekeliling, sekitar. Lingkungan adalah bulatan yang mengelilingi atau melingkari, sekalian yang terlingkung di suatu daerah sekitarnya. Menurut Ensiklopedia Indonesia (1983) dalam Neolaka (2008) Lingkungan adalah segala sesuatu yang ada di luar suatu organism, meliputi : (1) Lingkungan Mati (abiotik), yaitu lingkungan di luar suatu organisme yang terdiri atas benda atau foktor alam yang tidak hidup, seperti bahan kimia, suhu, cahaya, gravitasi, atmosfer, dan lainnya, (2) Lingkungan Hidup (biotik), yaitu lingkungan di luar suatu organism yang terdiri atas organisme hidup, seperti tumbuhan, hewan, dan manusia.
Kebersihan lingkungan mempunyai arti sebuah keadaan bebas dari kotoran, termasuk di antaranya, debu, sampah, dan bau. Kebersihan merupakan upaya menusia umtuk memelihara diri dan lingkungannya dari segala yang kotor dan keji dalam rangka mewujudkan dan melestarikan kehidupan yang sehat dan nyaman. Kebersihan merupakan syarat bagi terwujudnya kesehatan, dan sehat adalah salah satu faktor yang dapat memberikan kebahagiaan. Sebaliknya kotor tidak saja merusak keindahan tetapi juga dapat menyebabkan timbulnya berbagai penyakit, dan sakit merupakan salah satu faktor yang mengakibatkan penderitaan.

\section{METODE PENELITIAN}

Berdasarkan pertanyaan peneliti dan tujuan penelitian, maka penelitian ini digolongkan dalam jenis penelitian kualitatif. Penelitian kualitatif Menurut Sugiyono (2014) adalah metode penelitian yang berlandaskan pada filsafat postpositivisme, digunakan untuk meneliti pada kondisi obyek yang alamiah, dimana peneliti adalah sebagai instrumen kunci, teknik pengumpulan data dilakukan secara triangulasi (gabungan), analisis data berbasis induktif/kualitatif, dan hasil penelitian lebih menekankan makna dari pada generalisasi.

Penelitian ini dilakukan di Dua Jorong yaitu, Jorong Pondok dan Jorong Pasa Lamo Kecamatan Sasak Ranah Pasisie Kabupaten Pasaman Barat. 
Penelitian ini dilakukan pada bulan

November sampai Desember 2017

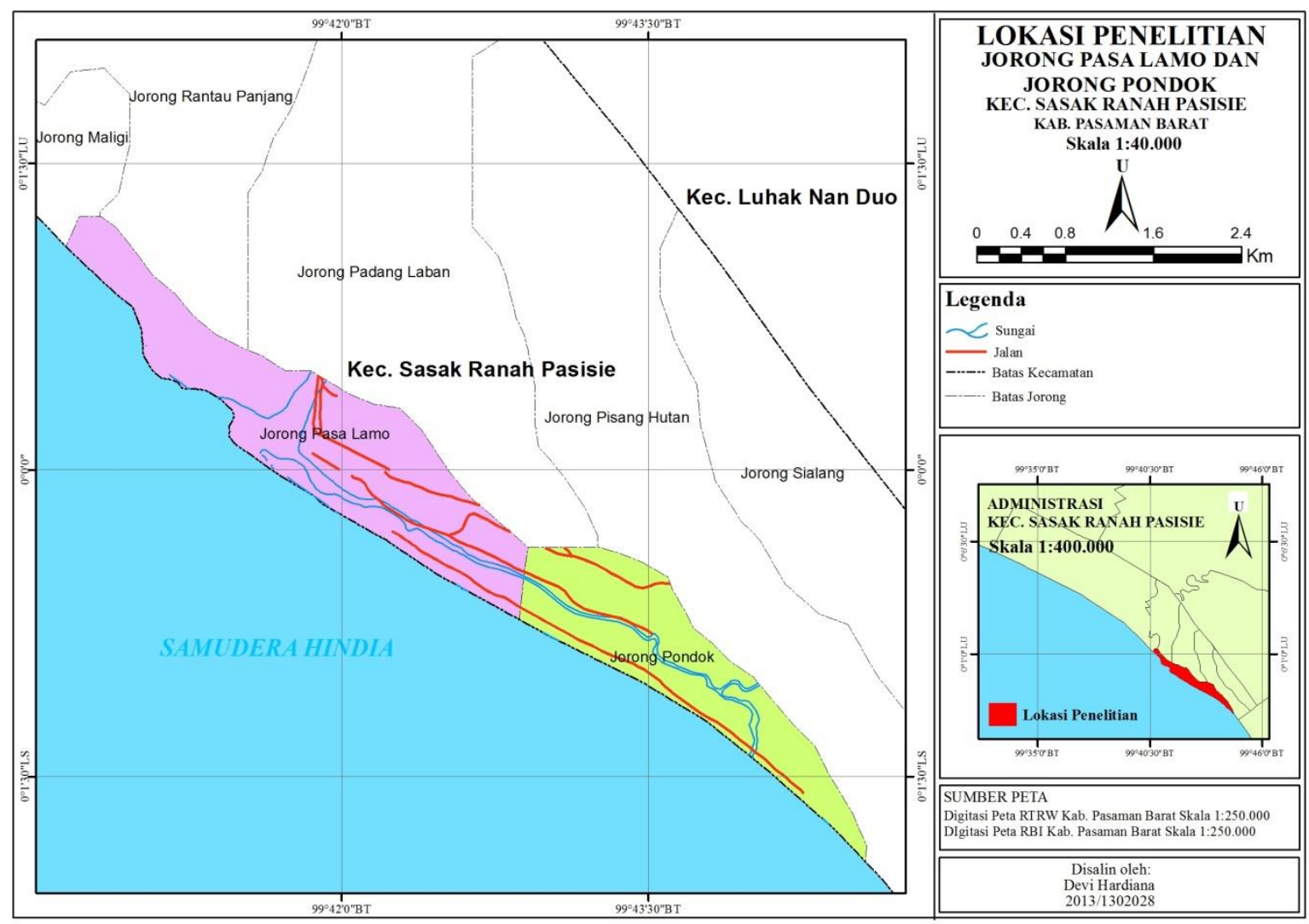

Gambar 1. Peta Lokasi Penelitian

Informan pada penelitian ini adalah Masyarakat, sedangkan informan kunci adalah Camat, Wali Nagari, dan Jorong. Pemilihan informan ini tentukan atas dasar peneliti menganggap informan tersebut bisa memberikan informasi mengenai perilaku masyarakat terhadap kebersihan lingkungan pantai.

Teknik pemilihan informan dilakukan secara Snowball Sampling. Menurut Sugiyono (2014) teknik pemilihan Informan penelitian Snowball Sampling yaitu adalah teknik pengambilan sampel sumber data, yang pada awalnya jumlahnya sedikit, lama- lama menjadi besar. Hal ini dilakukan karena dari jumlah yang sedikit belum mampu memberikan data yang memuaskan. Maka perlu mencari orang lain lagi yang dapat digunakan sebagai sumber data. Dengan demikian jumlah sampel sumber data akan semakin besar. Jumlah informan pada penelitian ini sebanyak 30 orang.

Untuk memperoleh data yang berkualitas di perlukan teknik pengumpulan data yang sesuai dengan jenis data yang di gunaka dalam penelitian ini. Teknik pengumpulan data dilakukan dengan cara observasi, 
wawancara dan dokumentasi, sedangkan untuk teknik analisis data dilakukan dengan cara pengumpulan data, reduksi data, penyajian data dan penarikan kesimpulan. Teknik keabsahan data dilakukan dengan cara perpanjangan keikutsertaan, ketentuan dalam pengamatan, triangulasi.

\section{HASIL DAN PEMBAHASAN}

\section{Perilaku Masyarakat Dalam Menjaga Kebersihan Lingkungan Pantai Kecamatan Sasak Ranah Pasisie.}

Prilaku masyarakat kurang baik dalam menjaga kebersihan lingkungan pantai, karena masyarakat yang tinggal di lingkungan pantai membuang sampah hasil dari rumah tangga kepinggir pantai, limbah air garam yang berasal dari masyarakat yang berprofesi sebagai pengrajin ikan asin dibuang ke pinggir pantai karena tidak ada tempat untuk membuang limbah tersebut, dengan demikian hal itu lah yang memicu bau busuk yang berasal dari limbah air garam tersebut dan akibat dari itu mempengaruhi kebersihan pantai.

Masyarakat yang berprofesi sebagai pengrajin ikan asin juga membuang sisa kepala ikan, isi dalam perut ikan, sisik ikan, dan insang ikan ke pinggir pantai. Tidak hanya itu sebagaian masyarakat yang memiliki ternak peliharaan seperti sapi dibiarkan kotoran nya di pinggir pantai tanpa dilakukan tindakan lanjutan seperti pengolahan kotoran sapi tersebut, kemudian kandang sapi ternak milik masyarakat berada di pinggir pantai. Masyarakat yang bermukim dipinggir pantai sebagian besar tidak memiliki wc, hal tersebut membuat masyarakat yang tidak mempunyai wc buang air besar ke pinggir pantai, bahkan ada dari sebagaian yang buang air besar ke semak-semak. Kurang nya pengetahuan masyarakat tentang pentingnya hidup sehat dan bersih menjadi salah satu pemicu masyarakat melakukan perilaku tidak baik terhadap lingkungan khususnya dalam hal menjaga kebersihan lingkungan. Tidak adanya pengawasan yang khusus dari pemerintah terkait dan tidakan lanjutan tentang adanya larangan membuang sampah dan buang air besar sembarangan berupa sangsi yang diberikan.

\section{Upaya Masyarakat Dalam Menjaga Kebersihan Lingkungan Pantai Kecamatan Sasak Ranah Pasisie.}

Upaya masyarakat menjaga kebersihan pantai dilakukan dengan cara membersihkan lingkungan rumah masing-masing yang berada dilingkungan pantai, untuk masalah sampah upaya yang dilakukan masyarakat hanya membakar nya saja tanpa adanya tindakan lanjutan seperti pengelolaan atau mendaur ulang sampah tersebut. Kurangnya pengetahuan dan kesadaran masyarakat tentang kebersihan dan hidup sehat membuat lingkungan tidak bersih dan terjaga. 
Upaya yang dilakukan masyarakat dan jorong adalah gotong rpypng bersama tetapi hal itu jarang dilakukan. Gotong royong bersama yang dilakukan tidak rutin setiap bulannya karena masyarakat sendiri tidak antusias dalam kegiatan gotong royong tersebut, hal yang menjadi alasan tidak dilakukannya kegiatan gotong royong secara rutin setiap bulannya dalah karena profesi pekerjaan masyarakat sekitar yang mayoritas nelayan, yang diketahui bahwa kegiatan penangkapan ikan dilakukan tidak beratur diantaranya dilakukan di pagi hari, siang, sore bahkan malam hari dan sebagian nelayan ada yang bermalam dilakut bahkan serhari-hari. Kesibukan dan aktifitas masyarakat menjadi alasan juga kenapa tidak terjadinya gotong royong karena untuk mencocokkan dan menentukan kapan hari yang bisa dilakukan untuk gotong royong bersama.

3. Peran Pemerintah Daerah Dalam Menjaga Kebersihan Lingkungan Pantai Kecamatan Sasak Ranah Pasisie.

Pemerintah sudah melakukan cara untuk menjaga kebersihan lingkungan pantai dengan cara dibentuk nya program Pokdarwis yaitu Kelompok Sadar Wisata. Pokdarwis juga melakukan kegiatan-kegiatan bersih-bersih pantai dengan melibatkan masyarakat yang ada dilingkungan pantai. Pemerintah juga telah memberikan tempat sampah berupa potongan drum dan tong sampah plastik yang di sebar dibeberapa titik seperti di tempat Objek Wisata yang ada di pantai sasak, Sekolah, dan Tempat Pendidikan Alquran. Kemudian dalam kegiatan MCK Pemda juga telah memberikan sarana kepada masyarakat berupa sumur yang bisa dimanfaatkan oleh masyarakat terutama bagi masyarakat yang tidak memiliki sumur dan WC umum yang bisa dimanfaatkan oleh masyarakat.

\section{PENUTUP}

\section{A. Kesimpulan}

Berdasarkan hasil penelitian dan pembahasan dalam penelitian mengenai Kepedulian Masyarakat Dalam Menjaga Kebersihan Lingkungan Pantai Kecamatan Sasak Ranah Pasisie dapat disimpulkan bahwa, perilaku masyarakat dalam menjaga kebersihan lingkungan Pantai Sasak kurang mencerminkan prilaku yang menjaga kebersihan lingkungan Pantai. Prilaku masyarakat yaitu membuang sampah, mengumpulkan lalu kemudian membakarnya dan masyarakat juga membuang kotoran sapi di pinggir Pantai serta masih ada dari masyarakat yang buang air besar di pinggir Pantai.

$\begin{array}{lr}\text { Upaya yang } & \text { dilakukan } \\ \text { masyarakat dalam } & \text { menjaga } \\ \text { kebersihan lingkungan Pantai Sasak } \\ \text { hanya membersihkan lingkungan } \\ \text { pekarangan rumah sendiri, dan untuk }\end{array}$


sampah masyarakat hanya membakarnya saja, sedangkan untuk gotong royong bersama jarang dilakukan dan untuk membersihkan lingkungan Pantai Sasak.

Peran pemerintah dalam menjaga kebersihan lingkungan Pantai sudah dikatakan baik, pemerintah sendiri telah ikut perperan dalam menjaga kebersihan pantai dengan membentuk program Pokdarwis dan menyediakan beberapa fasilitas atau sarana penunjang seperti disediakannya tempat sampah, sumur, WC umum yang bisa dilakukan untuk kegiatan MCK oleh masyarakat sekitar.

\section{B. SARAN}

Berdasarkan kesimpulan di atas, maka peneliti mengajukan saran beberapa hal berikut:

1. Masyarakat diharapkan dapat memiliki prilaku yang baik dalam menjaga kebersihan lingkungan Pantai Sasak dengan cara tidak membuang dan mengumpulkan sampah di pinggir pantai dan diharapkan masyarakat menghilangan kebiasaan untuk buang air besar disembarang tempat khususnya dipinggir pantai.

2. Kepada masyarakat diharapkan agar berupaya menciptakan lingkungan pantai yang bersih dan nyaman dengan cara melakukan tindakan yang baik dalam mengelola sampah.

3. Kepada masyarakat beserta jorong dan wali nagari diharapkan melakukan kegiatan gotong royong bersama secara rutin agar terciptanya lingkungan yang bersih.

4. kepada Pemerintah Daerah yang terkait agar serta ikut berperan bersama-sama dalam meciptakan lingkungan yang bersih, sehat dan nyaman, dengan melakukan penyuluhan dan sosialisasi hidup sehat dan bersih kepada masyarakat agar terciptanya lingkungan yang bersih dan sehat.

\section{DAFTAR PUSTAKA}

Arifin, S. 2012. Hukum Perlindungan dan Pengelolaan Lingkungan Hidup di Indonesia. Jakarta: PT Sofmedia.

Azwar, A.1979. Pengantar Ilmu Kesehatan Lingkungan. Jakarta: PT Mutiara Sumber Daya.

Azwar, S. 2005. Perilaku Manusia Teori dan Pengukurannya. Yogyakarta: Pustaka Belajar

Iswandi.2012.Ekologi dan Ilmu Lingkungan. Padang: UNP Press.

Nazaruddin. 2014. Analisis Perilaku Masyarakat Dalam Mnciptakan Kebersihan Lingkungan Di Kota Pekanbaru. No 2. Vol 1: Hal 1.

Noelaka, A. 2008. Kesadaran Lingkungan. Jakarta: PT Rineka Cipta.

Nugroho, K. 2007. Laporan Penelitian: Manajemen Pemilahan Sampah di Stasiun Tugu Yogyakarta 
Tahun 2007, dalam

http://uripsantoso.wordpress.com

/2008/12/22/pentingnya-

pemilahan-sampah/.

Poerwadarminta. 1983. Kamus Besar

Bahasa Indonesia. Jakarta :

Balai Pustaka

Sugiyono. 2014. Metodologi Penelitian Kuantitatif, Kualitatif, dan $R \& D$. Bandung: Alfabeta.

Thoha, M. 2008. Perilaku Organisasi Konsep Dasar dan Aplikasinya. Jakarta: Pt Raya Grafindo. 